\title{
ANALISIS PERKEMBANGAN KEMANDIRIAN TERHADAP KEMAMPUAN PENYESUAIAN DIRI SISWA KELAS I DAN KELAS V
}

Yuris Indri Persada ${ }^{1}$, Yulia Eka Yanti ${ }^{2}$, Nabila Azzahra Bil Haqqi ${ }^{3}$, Ida Royani ${ }^{4}$ 1,2,3,4 PGSD Universitas Islam Raden Rahmat Malang

1yurispersada@gmail.com

2yulia.ekay@uniramalang.ac.id,

3nabilabilhaqqi@gmail.com

\begin{abstract}
The Effect of Independence Development to Self-Adjustment Abilities of $1^{\text {st }}$ Grade and $5^{\text {th }}$ Grade Students. The development of independence and adaptation ability is an important thing and must be passed by every student's development. In this study, research was conducted on $5^{\text {th }}$ grade students and $1^{\text {st }}$ grade student. The result is the $5^{\text {th }}$ grade student had better development of independence and selfadjustment abilities than $1^{\text {st }}$ grade student.
\end{abstract}

Keywords: Independence, Adaptation, Elementary School Students

\begin{abstract}
ABSTRAK
Perkembangan kemandirian dan kemampuan penyesuaian diri adalah suatu hal yang penting dan wajib dilewati oleh setiap perkembangan siswa. Pada penelitian ini dilakukan penelitian kepada 5 siswa kelas I dan V siswa kelas V. Hasil penelitian diperoleh bahwa siswa kelas $\mathrm{V}$ memiliki perkembangan kemandirian dan kemampuan penyesuaian diri yang lebih baik daripada siswa kelas I.
\end{abstract}

Kata Kunci: Media Pembelajaran, KOSIR, motivasi belajar

\section{A. Pendahuluan}

Penanaman sikap kemandirian harus dilakukan sejak dini. Hal ini dikarenakan pada tahapan anak usia dini, mereka berada pada fase keemasan. Fase anak mampu mengembangkan berbagai kemampuan dan keterampilan dalam mengurus dirinya. Kemandirian menjadi faktor yang penting agar anak tidak bergantung pada orang lain dan mampu menjalani kehidupan dengan baik (Chairilsyah, 2019). Penyesuaian diri merupakan suatu proses yang mencakup respon mental dan tingkah laku individu sebagai usaha dalam menghadapi stress, frustasi dan konflik terhadap 
tuntutan di masyarakat dan lingkungan mereka berada (Schneiders, 1964 dalam Rusdiyanti, 2019). Oleh karena itu, lingkungan juga menjadi salah satu factor penting dalam mempengaruhi tahap perkembangan ini.

Perkembangan ini dipengaruhi oleh beberapa hal, salah satunya yakni pengalaman dan usia. Individu yang lebih dewasa cenderung memiliki perkembangan yang lebih baik dan berkembang daripada individu dengan usia dibawahnya. Namun hal ini tidak dapat menjadi tolak ukur yang valid karena ada banyak faktor yang mempengaruhi perkembangan kemandirian dan kemampuan penyesuaian diri seorang individu. Hal ini menjadikan landasan perlunya dilakukan sebuah penelitian berkaitan dengan perkembangan kemandirian dan kemampuan penyesuaian diri.

Dalam penelitian ini akan dilakukan penelitian dengan metode obsevasi pada siswa kelas I dan kelas $\mathrm{V}$ tingkat sekolah dasar untuk mengetahui perbedaan perkembangan kemandirian dan kemampuan penyesuaian diri siswa berdasarkan usianya. Manfaat yang dapat diperoleh dari penelitian ini yakni penulis dapat membuktikan prinsip perkembangan kemandirian dan penyesuaian diri serta implikasinya dalam dunia pendidikan.

\section{B. Metode Penelitian}

Metode yang dilakukan dalam penelitian ini adalah metode observasi secara langsung kepada siswa dan studi literatur. Penelitian dilakukan di Sekolah Dasar Islam Diponegoro Kecamatan Dampit Kabupaten Malang. Sampel yang diambil oleh penulis adalah siswa kelas I dan kelas V SD. Penelitian dilakukan dengan observasi perilaku siswa kelas I dan kelas $\mathrm{V}$ yang berkaitan dengan perkembangan kemandirian dan kemampuan penyesuaian diri selama 2 minggu.

\section{Jenis Penelitian}

Jenis penelitian ini yakni dilakukan dengan studi literatur dan observasi siswa secara langsung.

\section{Waktu dan TempatPenelitian}

Penelitian ini dilakukan pada tanggal 1 sampai dengan 14 Desember 2020 di SD Islam Diponegoro Kecamatan Dampit Kabupaten Malang.

Populasi dan Sampel 
Populasi dalam penelitian ini adalah 5 orang siswa kelas I dan 5 orang siswa kelas V SD Islam Diponegoro Kecamatan Dampit Kabupaten Malang. Pengambilan data dilakukan dengan observasi selama waktu tertentu. Sampel dalam penelitian ini yaitu kelas I sebagai kelas eksperimen dan kelas $\mathrm{V}$ sebagai kelas kontrol. Penamaan sampel dilakukan secara alfabetis dengan makna $1 \mathrm{~A}$ untuk siswa kelas 1 sampel ke 1, 1B untuk siswa kelas 1 sample ke 2 dan seterusnya.

\section{Prosedur Penelitian}

Prosedur penelitian dalam penelitian ini adalah observasi perilaku siswa kelas I dan kelas $\mathrm{V}$ yang berhubungan dengan perkembangan kemandirian dan kemampuan penyesuaian diri selama 2 minggu. Selanjutnya dilakukan dengan studi literatur yang berhubungan dengan perkembangan kemandirian dan kemampuan penyesuaian diri siswa usia Kelas 1 dan Kelas 5 Sekolah Dasar.

\section{Data, Instrumen dan Teknik}

Pengumpulan Data

Instrumen dalam penelitian ini adalah kesimpulan hasil observasi dan literatur mengenai penelitian serupa. Hasil observasi dianalisa dan ditarik kesimpulannya dengan metode diskusi antar penulis. Teknik pengumpulan data yang dilakukan adalah wawancara kepada siswa dan mengamati perilaku siswa untuk mengukur perkembangan kemandirian dan kemampuan penyesuaian diri siswa.

\section{Teknik Analisis Data}

Teknik analisis dari penelitian ini adalah penarikan kesimpulan dari proses observasi dan studi literatur yang dilakukan selama waktu tertentu yaitu dari tanggal 1-14 Desember 2020. Hipotesis dari penelitian ini adalah siswa kelas $\mathrm{V}$ akan memiliki kemandirian dan kemampuan penyesuaian diri yang lebih baik dan lebih berkembang dibandingkan dengan tingkat kemandirian dan kemampuan penyesuaian diri siswa kelas I Sekolah Dasar Islam Diponegoro Kecamatan Dampit Kabupaten Malang.

\section{C.Hasil Penelitian dan Pembahasan}

Hasil

Hasil dari observasi yang dilakukan penulis pada tanggal 1 
Desember 2020 sampai dengan 14 Desember 2020 pada 5 orang siswa kelas I dan kelas $\mathrm{V}$ dengan observasi beberapa indikator perkembangan kemandirian dan kemampuan penyesuaian diri ditunjukkan pada tabel berikut :



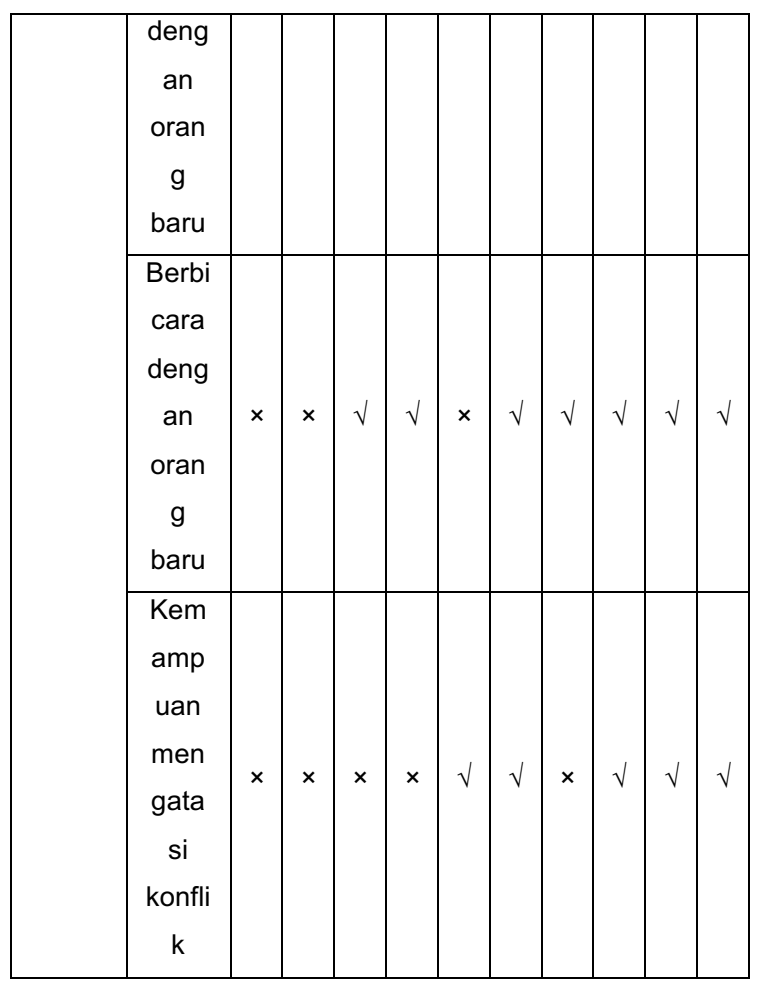

Tabel 1. Hasil Observasi dan Wawancara

Keterangan :

$\checkmark$ : Mampu

$\mathbf{x}$ : Belum mampu

Berdasarkan hasil observasi di atas, siswa kelas $\mathrm{V}$ akan memiliki perkembangan kemandirian dan kemampuan penyesuaian diri yang lebih baik dari siswa kelas I. Tabel diketahui bahwa mayoritas siswa kelas $\mathrm{V}$ dapat melakukan hal-hal yang menjadi indikator perkembangan kemandirian dan penyesuaian diri. Pada sampel, siswa kelas $\mathrm{V}$ yang belum mampu melaksanakan beberapa indikator, setelah diobservasi lebih lanjut terdapat faktor lain yang 
mempengaruhi

perkembangan

kemandirian dan kemampuan penyesuaian diri siswa. Sebagai contoh, sampel 5C belum mampu untuk berangkat sendiri ke sekolah saat teman-teman lainnya sudah mampu untuk berangkat sendiri ke sekolah.

Setelah diobservasi lebih lanjut hal ini dikarenakan jarak rumah sampel 5C ke sekolah cukup jauh dan melewati rute yang berbahaya sehingga orang tua masih mengantarkan siswa sampel $5 \mathrm{C}$ ke sekolah. Sampel siswa 5D belum mampu bekerja sama dengan orang baru saat teman-temannya sudah mampu bekerja sama dengan baik pada orang baru. Setelah observasi lebih lanjut, siswa sampel 5C adalah siswa yang pemalu dan cenderung lebih berhati-hati saat harus bekerja sama dengan orang baru sehingga penyesuaian diri dengan orang baru di sekitarnya juga lebih lambat daripada teman sebayanya.

Pada tabel poin sampel siswa kelas I, diketahui bahwa beberapa siswa kelas I dapat melakukan beberapa hal yang menjadi indikator perkembangan kemandirian dan kemampuan penyesuaian diri.
Beberapa siswa sudah mampu melakukan hal-hal sebagaimana yang dilakukan siswa kelas $\mathrm{V}$, namun beberapa juga ada yang belum mampu. Kemampuan melakukan hal yang menjadi indikator perkembangan kemandirian dan penyesuaian diri pada sampel siswa kelas I dipengaruhi oleh beberapa hal. Sebagai contoh, siswa sampel 1A mampu berangkat ke sekolah sendiri disaat teman-teman sebayanya belum mampu berangkat ke sekolah sendiri. Setelah dilakukan observasi lebih lanjut, siswa sampel $1 \mathrm{~A}$ memiliki jarak tempuh dari rumah ke sekolah yang dekat $\pm 500 \mathrm{~m}$. Siswa sampel 1C sudah mampu makan sendiri saat teman-teman sebayanya belum mampu. Setelah dilakukan observasi lebih lanjut, siswa sampel 1C memiliki adik yang masih berusia 5 bulan sehingga orang tua dari siswa sampel $1 \mathrm{C}$ sudah mengajarkan kemandirian berupa makan sendiri.

\section{Pembahasan}

Berdasarkan hasil penelitian diatas, dapat disimpulkan bahwa perkembangan kemandirian dan kemampuan penyesuaian diri siswa kelas $\mathrm{V}$ lebih baik dan lebih 
berkembang daripada perkembangan kemandirian dan kemampuan penyesuaian diri siswa kelas I. Kemandirian merupakan suatu sikap yang diperoleh secara kumulatif melalui proses menuju kemandirian. Setiap individu akan belajar untuk menghadapi berbagai situasi dalam lingkungannya sampai individu tersebut mampu berpikir dan mengambil tindakan yang tepat dalam mengatasi setiap situasi (Sa'diyah, 2017). Sehingga siswa kelas $\mathrm{V}$ yang memiliki pengalaman hidup yang lebih banyak daripada siswa kelas I akan memiliki banyak pengalaman untuk menghadapi berbagai situasi dalam kehidupannya yang menuntunnya menjadi individu yang lebih mandiri.

Perkembangan kemandirian dan kemampuan penyesuaian diri siswa kelas $\mathrm{V}$ yang lebih berkembang dibandingkan siswa kelas I juga dipengaruhi oleh beberapa hal. Salah satu hal yang mempengaruhi adalah interaksi dengan lingkungan sosialnya. Berinteraksi dengan orang lain dapat membuat anak mengalami perkembangan yang cenderung mempengaruhi kemampuan penyesuaian diri anak (Rusdiyanti, 2019).
Kemandirian

seseorang dipengaruhi oleh beberapa factor, (Jannah, 2013) faktor yang mempengaruhi kemandirian dan penyesuaian diri seseorang yang pertama adalah faktor internal yaitu emosi dan intelektual. Faktor kedua adalah faktor eksternal yang terdiri dari lingkungan, karakteristik sosial, stimulus, pola asuh, cinta dan kasih sayang, kualitas interaksi antara anak dan orangtua, dan pendidikan orang tua. Pada hasil penelitian diatas diketahui bahwa tidak seluruh siswa kelas $V$ memiliki indikator perkembangan kemandirian dan kemampuan penyesuaian diri dalam dirinya yang sama. Siswa kelas V yang belum memiliki indikator perkembangan kemandirian dan kemampuan penyesuaian diri dapat dipengaruhi oleh banyak hal. Sebagai contoh, salah satu sampel diketahui belum dapat berangkat ke sekolah sendirian saat teman sebayanya sudah mampu melakukan hal tersebut. Hal ini dikarenakan jarak yang jauh antara rumah dan sekolah, sehingga indikator perkembangan kemandirian berangkat ke sekolah sendiri tidak dapat dilakukan karena faktor eksternal siswa. Sampel kelas $\mathrm{V}$ lainnya yang belum mampu 
melakukan indikator kemampuan penyesuaian diri dikarenakan individu tersebut memiliki sikap pemalu. Sehingga sampel tersebut belum mampu menyesuaikan diri dengan lingkungan secara maksimal seperti teman sebayanya karena faktor internal.

Peserta didik perlu memiliki kemandirian dalam belajar (Wedemeyer 2012 dalam Lestari, 2015). Hal ini dimaksudkan supaya mereka bisa bertanggung jawab dalam mengatur dan mendisiplinkan dirinya sendiri, dalam mengembangkan kemampuan belajar atas kemauannya sendiri.

Penyesuaian diri terhadap teman sebaya juga sangat penting bagi perkembangan siswa terutama perkembangan sosial mereka. Dalam proses penyesuaian ini, siswa seringkali dihadapkan pada suatu masalah yaitu penolakan atau penerimaan dalam pergaulannya. Apabila seorang siswa tersebut ditolak dalam pergaulan yang baru, mereka akan mengalami kekecewaan. Untuk menghindari hal tersebut siswa perlu memiliki sikap perasaan dalam keterampilan perilaku yang dapat menunjang penerimaan dalam pergaulan. Meskipun dalam usaha penyesuaian diri dengan teman sebaya lebih banyak mengalahkan kepentingan pribadi dengan kepentingan kelompok dengan alasan takut dikucilkan, akan tetapi secara perlahan-lahan siswa akan mengalami kesetabilan dan timbul rasa percaya diri dalam pergaulannya tersebut.

Untuk memproses penyesuaian diri setidaknya melibatkan beberapa unsur, seperti memotivasi dengan motivasi dapat dikatakan sebagai kunci untuk memahami proses penyesuaian diri, motivasi dapat dikatakan sama halnya dengan kebutuhan, perasaan, dan emosi. Persaan itu merupakan kekuatan internal yang menyebabkan ketegangan dan ketidakseimbangan dalam organisme perasaan. Karena sesungguhnya kebebasan dan ketegangan adalah kekuatan internal yang lebih wajar dalam organisme apabila dibandingkan dengan kedua kondisi tersebut (Ali, 2005 dalam Nurfuad, 2013).

Kemampuan penyesuaian diri siswa juga dipengaruhi oleh keadaan sosialnya. Siswa yang memiliki 
kemampuan penyesuaian diri yang baik juga memiliki lingkungan sosial teman sebaya yang kemampuan penyesuaian dirinya baik. Hal ini terjadi karena lingkungan sosial teman sebaya dan kemampuan penyesuaian diri siswa memiliki hubungan yang berbanding lurus, artinya semakin baik tinggi dukungan sosial teman sebaya, akan semakin tinggi pula kemampuan penyesuaian diri siswa (Hasan dan Handayani, 2014).

\section{E. Kesimpulan}

$\begin{array}{ccc}\text { Pada hasil penelitian diatas } \\ \text { dapat } & \text { diketahui bahwa }\end{array}$
perkembangan kemandirian dan kemampuan penyesuaian diri adalah suatu hal yang saling berhubungan. Kemandirian yang berkembang baik seiring dengan kemampuan penyesuaian diri siswa. Kemandirian dan penyesuaian diri dari siswa kelas $\mathrm{V}$ berbeda dengan siswa kelas I. Ada siswa yang berkembang sejalan dengan sebayanya, ada siswa yang berkembang lebih cepat daripada sebayanya dan ada siswa yang berkembang lebih lambat daripada sebayanya. Hal ini dipengaruhi oleh faktor internal dan faktor eksternal dari masing-masing siswa.
Saran yang dapat diberikan oleh penulis pada penilitian selanjutnya adalah melakukan penelitian dengan subjek penelitian yang lebih bervariasi dan metode pengolahan data yang lebih baik agar didapatkan hasil yang lebih akurat.

\section{DAFTAR PUSTAKA}

Chairilsyah, David (2019). Analisis Kemandirian Anak Usia Dini. PAUD Lectura : Jurnal Pendidikan Anak Usia Dini, 3(1), 2598-2524.

Hasan, S. A., Handayani, M. M. (2014). Hubungan antara Dukungan Sosial Teman Sebaya dengan Penyesuaian Diri Siswa Tunarungu di Sekolah Inklusi. JURNAL Psikologi Pendidikan dan Perkembangan, 3(2), 128-135.

Lestari, Indah (2015). Pengembangan Layanan Informasi Teknik Symbolic Model dalam Membantu Mengembangkan Kemandirian Belajar Anak Usia Sekolah Dasar. Jurnal Konseling GUSJIGANG. 1(1). 1-12

Nurfuad, Achlis. 2013. Meningkatkan Penyesuaian Diri Terhadap Lingkungan Sekolah Melalui Layanan Bimbingan Kelompok Pada Siswa Kelas VII B SMP N 2 Juwana Tahun 2012/2013. Malang : Universitas Negeri Semarang.

Rusdiyanti, I. G. A. D., Budisetyani, I. G. A. P. W (2019). Penyesuaian Diri Anak Berbakat Intelektual Dengan Pola Asuh Otoritarian. 
Jurnal Psikologi Udayana, 6(2), 389-399.

Sa'diyah, Rika (2017). Pentingnya Melatih Kemandirian Anak. KORDINAT, 16(1). 33-46. 